MACIEJ PEPLINSKI

Instytut Sztuk Audiowizualnych Uniwersytet Jagielloński w Krakowie Leibniz-Institut für Geschichte und Kultur des östlichen Europa (GWZO)
Images

vol. XXVIII/no. 37

Poznań 2020

ISSN 1731-45OX

\title{
Gatunek na ustugach doktryny. Ideologia w polsko-enerdowskiej koprodukcji Milcząca gwiazda
}

\begin{abstract}
AвSTract. Peplinski Maciej, Gatunek na usługach doktryny. Ideologia w polsko-enerdowskiej koprodukcji Milcząca gwiazda [Genre at service of the doctrine. Ideology in the East-German-Polish co-production The Silent Star]. "Images" vol. XXVIII, no. 37. Poznań 2020. Adam Mickiewicz University Press. Pp. 77-97. ISSN 1731-450X. DOI 10.14746/i.2020.37.05.

The East German-Polish co-production The Silent Star (1960, Kurt Maetzig) belongs to the group of early postwar Eastern European science fiction films which still remain barely examined by film and genre historians. The article summarizes the existing research on the film and investigates not only the specific formal character of Maetzig's unprecedented project, but also the numerous ideological and political motivations which stood behind it.

KeyworDs: The Silent Star, Der schweigende Stern, The Astronauts, Kurt Maetzig, Stanisław Lem, GDR, Polish People's Republic, coproduction, film genre, science fiction, socialism, cosmos, space program, space race
\end{abstract}

Wydaje się, że w ramach historycznych badań nad filmowym science fiction (sf) docieramy do punktu, w którym rzeczywistość czasami zaczyna przypominać fikcję znaną z wielu tworzących ten gatunek dzieł. Mam na myśli filmoznawcze podróże w czasie, mające na celu nawiązanie pierwszego (badawczego) kontaktu z utworami, które nie trafiły do kanonów, posługują się archaicznymi już stylami i estetykami, były uznawane za zaginione, pochodzą z wczesnych, często pomijanych historycznych okresów rozwoju kina lub funkcjonowały poza uniwersum zachodniej, komercyjnej rozrywki filmowej, przynależąc do peryferyjnych, czasami już nieistniejących kinematografii. Za takie wracające obecnie do kulturoznawczego obiegu filmy sf można uznać między innymi radzieckie Niebo wzywa[1] (1959, M. Karjukow, A. Kozyr), duński Niebiański statek[2] (1918, Holger-Madsen) i czechosłowacką Ikarię XB 1[3] (1963, J. Polák).

Powyższa obserwacja okazuje się szczególnie trafna również w odniesieniu do polsko-enerdowskiej koprodukcji Milczaca gwiazda (niem. tytuł Der schweigende Stern) z 1960 roku. Punkt wyjścia futu-

[1] Por. M. Schwartz, The Heavens Call, <http://sensesofcinema.com/2007/cteq/heavens-call/>, dostęp: 26.03.2020.

[2] Por. M. Peplinski, Niebiański statek, „Ekrany” 2018, nr 1 (38), s. 69-67.
[3] Por. M. Uhliřova, Voyage through space, time and utopian modernism in Ikarie XB 1, [w:] Czech Cinema Revisited: politics, aesthetics, genres and techniques, red. L. Česálková, Praha 2017, s. 338-365. 
rystycznej historii opowiedzianej w dziele Kurta Maetziga stanowi niespodziewane odkrycie na Ziemi tajemniczej szpuli, która zawiera zakodowaną wiadomość od reprezentantów cywilizacji zamieszkującej Wenus. Za uderzająco symboliczne w tym kontekście można uznać ujęcie z samego początku filmu, w którym widzimy wenusjańską szpulę umieszczoną - niczym rolka filmu - w obrotowym mechanizmie służącym do jej oczyszczenia przed podjęciem ostatecznych analiz. Tę wybitnie kinematograficzną metaforę (oczywiście niezamierzoną przez twórców, dostrzegalną dla badacza dopiero dziś, ponad 60 lat od premiery filmu) dopełnia fakt, że uzyskana później poprzez obracanie szpuli treść zostaje przełożona w laboratorium na sygnał audiowizualny - serię abstrakcyjnych obrazów i dźwięków, które powoli układają się w zrozumiały dla ludzi komunikat.

Żeby prześledzić twórcze i producenckie intencje, które zadecydowały o powstaniu i estetycznym kształcie Milczacej gwiazdy, trzeba ją dziś potraktować - zupełnie niczym naukowcy w pierwszych sekwencjach filmu - jako tajemniczy artefakt pochodzący ze swoistej alien culture (socjalistyczna kultura filmowa nieistniejących już Niemiec Wschodnich) oraz podatny na rozkodowanie tylko dzięki dogłębnej kontekstualizacji historycznej. Artefakt ten, choć retrospektywnie uznaje się go dziś za nieudany i nieznośnie socrealistyczny, ma istotną wartość kulturową, ponieważ, po pierwsze, reprezentuje grupę filmów inicjujących gatunek w powojennej, socjalistycznej Europie Środkowej i Wschodniej oraz, po drugie, ukazuje propagandowe motywacje i ogromne ambicje produkcyjne, z jakimi do fantastyki naukowej podeszły reżimy komunistyczne na przełomie lat pięćdziesiątych i sześćdziesiątych.

Historyczna misja

Milcząca gwiazda była pierwszą powstałą przy udziale PRL-owskiej kinematografii produkcją, która realizowała dwa z najbardziej sztandarowych motywów kojarzonych z sf: podróż kosmiczna i first contact. Z odrobiną dobrej woli można więc ten film nazwać pierwszym polskim powojennym filmem science fiction - choć jednocześnie, o czym wspomnę w dalszych częściach tekstu, projekt ten należy postrzegać jako przedsięwzięcie znacznie bardziej enerdowskie niż polskie.

Już bez angażowania dobrej woli można Milczącą gwiazdę uznać za pierwszą w historii filmową adaptację prozy Stanisława Lema. Literacką podstawę scenariusza stanowiła opublikowana w Polsce w 1951 roku powieść Astronauci. Książka Lema - jak również jego wcześniejsze i późniejsze opowiadania - cieszyły się wówczas w bloku wschodnim dużą popularnością i przyczyniły się do rozwoju popularności wschodnioeuropejskiej, odpowiednio nasyconej ideologicznie literackiej fantastyki naukowej[4]. Oprócz tekstów Lema klasykiem tamtego okresu stała się powieść rosyjskiego autora Iwana Jefremowa Mgławica Andromedy z 1957 roku.

[4] M. Schwartz, Die Erfindung des Kosmos: zur sowjetischen Science Fiction und populärwissenschaftlichen
Publizistik vom Sputnikflug bis zum Ende der Tauwetterzeit, Frankfurt am Main, New York 2003, s. 108-130. 
Scenariusz Milczącej gwiazdy okazał się niezbyt wierną adaptacją Astronautów. Jedna z głównych różnic między filmem a książką dotyczy dystansu czasowego względem opowiadanych wydarzeń. Historia przedstawiona w filmie nie dzieje się, jak miało to miejsce w powieści, w roku 2003, lecz już na przełomie lat sześćdziesiątych i siedemdziesiątych XX wieku. Dzieło Maetziga miało więc antycypować światowy rozwój z dużą dozą optymizmu, tworząc wrażenie, że ludzkości uda się osiągnąć fenomenalny postęp już w ciągu dekady od momentu powstania filmu.

W momencie odkrycia tajemniczej wiadomości z Wenus Ziemia podzielona jest między dwa pokojowo koegzystujące mocarstwa. Liderzy bloku państw komunistycznych - gdzie, jak się wydaje, społeczeństwa są w pełni bezklasowe oraz nie istnieją już pieniądz i własność prywatna - podejmują decyzję o organizacji lotu na sąsiednią planetę w celu nawiązania kontaktu $\mathrm{z}$ tamtejszą cywilizacją. Załogę misji stanowi zespół składający się w większości z oddanych sprawie naukowców obok niemieckiego pilota, radzieckiego kosmonauty i pochodzącego z Afryki radiotechnika do składu misji należą: polski inżynier, japońska lekarka, chiński biolog i językoznawca, hinduski matematyk oraz amerykański fizyk. Po dotarciu na Wenus dzielni kosmonauci odkrywają koszmarną przeszłość tamtejszej wspólnoty. Nasi kosmiczni sąsiedzi, którzy planowali interplanetarny atak mający na celu zniszczenie Ziemi, dokonali samozagłady za pomocą broni jądrowej. Odkrywanie martwego globu kosztuje życie trzech członków misji. Pozostali przy życiu uczeni wracają na rodzimą planetę jako herosi, którzy stanęli na wysokości zadania dzięki absolutnemu kolektywnemu poświęceniu.

Kolektyw szlachetnych naukowców jako bohater zbiorowy, łatwa do odczytania polaryzacja ideologiczna w obrębie świata przedstawionego, utopijna wizja przyszłości, promocja międzynarodowej współpracy naukowej, krytyka użycia broni atomowej oraz patetyczny, niepozbawiony dydaktycznych i moralizujących tonów happy end - już owo krótkie podsumowanie elementów wyróżniających treść Milczącej gwiazdy każe przypuszczać, że mamy do czynienia z dziełem, które zostało skonstruowane ściśle według doktrynalnych oczekiwań socjalistycznego reżimu. Jakie dokładnie motywacje oraz kwestie polityczne, ideologiczne i kulturowo-estetyczne znalazły swoje odzwierciedlenie w filmie?

Trwające aż trzy lata (1956-1959) prace produkcyjne nad Milcząca gwiazda przypadły na okres odwilży, którą nastąpiła w bloku wschodnim po śmierci Stalina oraz przejęciu po 1956 roku funkcji przywódcy ZSRR przez Nikitę Chruszczowa. Nowy lider Związku Radzieckiego odrzucił stalinowski terror, zaczął mówić o pokojowej koegzystencji z Zachodem oraz zezwolił na społeczne kontrolowane otwarcie. W partyjnym i akademickim dyskursie, jak również, co najważniejsze, w kulturach narodowych poszczególnych demokracji ludowych dało się odczuć odejście od twardej stalinowskiej linii na rzecz stopniowej, 
trwającej kilka lat liberalizacji. W Niemczech Wschodnich z różnych przyczyn wewnętrznych odwilż trwała krótko i z pewnością nie była tak intensywna i problematyczna dla komunistycznego systemu, jak na przykład w Polsce po październiku 1956 roku[5]. Niemniej dokonała się w NRD charakterystyczna wówczas dla całego bloku wschodniego przemiana dotycząca kina popularnego. Po pierwsze, na fali rozluźnienia stosunków międzynarodowych oraz w celu zwiększenia atrakcyjności krajowej oferty kinowej reprezentanci wschodnioniemieckiej kinematografii mogli zacząć poszukiwać możliwości koprodukowania filmów z zagranicznymi partnerami. Po drugie, instancje zarządzające enerdowskim przemysłem filmowym dostrzegły, że wbrew założeniom zideologizowanej, promującej socrealizm polityki kulturalnej rodzime filmy nie mogą być tylko przezroczyste formalnie, deklaratywne politycznie oraz wychowujące w duchu marksizmu-leninizmu, ale również powinny zachwycać na poziomie doświadczenia audiowizualnego, kojarzyć się ze znanymi gatunkami, trzymać w napięciu, od czasu do czasu opowiadać o zwykłych ludzkich uczuciach i emocjach, pomagać zapomnieć o problemach doczesności czy nawet nieznacznie, najczęściej drogą niewinnego momentu comic relief, dystansować się do ideologii. Milcząca gwiazda stanowi jeden z pierwszych wyrazistych przykładów kompromisu, jaki szefostwo wschodnioniemieckiej wytwórni filmowej Deutsche Film-Aktiengesellschaft (DEFA) we współpracy z ministerstwem kultury NRD starały się wypracować w zakresie rozrywki, która miała wzbudzać szerokie zainteresowanie publiczności i przyciągnąć ją do kin oraz, jednocześnie, utrwalać jedyny właściwy światopogląd i odwracać uwagę od trudów socjalistycznej codzienności, jak i od problematycznych dla reżimu wydarzeń (jak na przykład zarządzona niedługo później budowa muru berlińskiego w 1961 roku).

Z jednej strony zatem film Maetziga był wyraźnie spozycjonowany ideologicznie, wyposażony w pozytywne przesłanie oraz bezpiecznie skonstruowany na poziomie estetyki i narracji - nie można więc było zastosować wobec niego typowych wówczas w partyjnym dyskursie oskarżeń o sianie defetyzmu i dekadencji, stosowanych standardowo wobec zachodniego kina autorskiego i rozrywkowego[6]. Z drugiej

[5] Za główną przyczynę słabej odwilży w NRD uznaje się napiętą sytuację polityczną w kraju po brutalnie spacyfikowanym powstaniu robotników w czerwcu 1953 roku - pierwszej w bloku wschodnim rebelii społecznej przeciwko komunistycznej władzy. Po wewnętrznym kryzysie i wizerunkowym blamażu wystraszony reżim enerdowski $\mathrm{z}$ dystansem podszedł do przemian, jakie od 1956 roku następowały w innych demokracjach ludowych. Por. A. Gwóźdź, Kino na biegunach: filmy niemieckie i ich historie 1949-1991, Gdańsk 2018, s. 20; Z. Kozik, Niemcy w NRD a polskie kryzysy 1956 i 1980-1981, Piotrków Trybunalski 1998, s. 33; K. Śliwińska, Socrealizm w PRL i NRD, Poznań 2006, s. 153-157.
[6] Na poziomie konstrukcji opowiadania Milczaca gwiazda w zasadzie jest filmem socrealistycznym. Dialogi wyróżnia deklaratywny ton, a narracja wydaje się bardzo uboga w chwyty niuansujące progresję wydarzeń. Można powiedzieć, że dzieło Maetziga jest, niczym socjalistyczna architektura, grubo ciosane oraz doskonale uodpornione na zarzut formalizmu. Zaczyna się jak film popularnonaukowy, podczas scen startu rakiety wykorzystuje bezbarwną stylistycznie estetykę transmisji telewizyjnej na żywo, a w ramach sekwencji lotu i pobytu na Wenus przekształca się w serię prostych scen-kluczy, które kreują czytelne socjalistyczne przesłanie, podkreślają bohaterstwo członków misji oraz sugestywnie wprowadzają 
strony, jako film gatunkowy, Milcząca gwiazda miała prowokować ekscytację wywołaną egzotyczną międzynarodową obsadą, futurystyczną tematyką, szeroką paletą barwną kolorowej taśmy filmowej oraz innowacyjnymi jak na tamte czasy efektami specjalnymi - zarówno wizualnymi, jak i akustycznymi.

Filmowa adaptacja Astronautów Lema, choć stanowiła niełatwe przedsięwzięcie oraz swoisty „test wyporności”[7] dla młodej wschodnioniemieckiej kinematografii, była forsowana jako prestiżowy projekt oraz potencjalnie bardzo dobry nośnik propagandy także dlatego, że końcówka lat pięćdziesiątych na pewnym istotnym obszarze okazała się dla bloku wschodniego krótkim, ale niezwykle efektownym momentem wzlotu. Mam na myśli fakt, że okres odwilży zbiegł się w czasie z kluczowymi osiągnięciami radzieckiego programu kosmicznego. Początkowe triumfy sowieckiej kosmonautyki - bezzałogowy lot Sputnika I w 1957 roku, loty psów i innych zwierząt w okresie 1957-1960, loty Gagarina i Titowa w 1961 roku, lot Tiereszkowej w 1963 roku, pierwszy spacer kosmiczny Leonowa w 1965 roku - oraz związane z nimi sukcesy radzieckiej nauki sprawiły, że wszystkie kraje socjalistyczne ogarnął sterowany przez partie i media entuzjazm dotyczący tematyki kosmosu, postępu naukowego oraz rozwoju nowoczesnych technologii transportu i komunikacji.

W wielu miastach za żelazną kurtyną zaczęto na początku lat sześćdziesiątych otwierać kina Kosmos [8]. Wizje rychłej pozaziemskiej ekspansji zalały media, materiały reklamowe, podręczniki edukacyjne i plakaty propagandowe[9]. Domy handlowe na terenach współczesnych państw bałtyckich oferowały „sputnikopodobne” odkurzacze o nazwie Saturnas. W Związku Radzieckim popularnonaukowe czasopisma publikujące teksty o podboju wszechświata - między innymi tytuły takie jak Nauka i żyźn, Technika-Mołodieży, Znanie-sila $i$ Wokrug swieta - osiągały nakłady wynoszące kilkaset tysięcy (!) egzemplarzy[10]. W Czechosłowacji dzieci bawiły się figurkami kosmonautów i zjeżdżały ze zjeżdżalni w kształcie rakiet[11], podczas gdy dorosłym rozdawano

poszczególne nastroje - dramatyczny, patetyczny lub komediowy. Zob. C. Pischel, Geschichten nach der Geschichte. Die zeitlichen Faltungen und Schichtungen des Science-Fiction-Films im Dienst des Staatssozialismus, [w:] Die Zukunft ist jetzt: Science-Fiction-Kino als audio-visueller Entwurf von Geschichte(n), Räumen und Klängen, red. A. Power, D. González de Reufels,

R. Greiner, W. Pauleit, Berlin 2016, s. 47-55.

[7] A. Gwóźdź, Kino na biegunach..., s. 34.

[8] Premierowe kino Kosmos, zbudowane w 1961 roku przy alei Karola Marksa w Berlinie Wschodnim, dysponowało największą w NRD salą projekcyjną (1001 miejsc). Bryła tylnej części budynku swoim kształtem przypominała stację księżycową lub masywny obiekt latający. W PRL otwarto w latach sześćdziesiątych i siedemdziesiątych kilkanaście kin Kosmos, między innymi w Katowicach, Kaliszu, Szczecinie, Gdańsku, Chojnicach, Przemyślu i Zambrowie. Zob. <http:// www.kinokompendium.de/kosmos_kino_berlin. htm $>$ oraz <https://www.gdanskstrefa.com/kino-kosmos-gdansk-kalisz-zambrow/> i <https://fotopolska. eu/>, dostęp: 26.03.2020.

[9] Por. J. Richers, Himmelssturm, Raumfahrt und „kosmische” Symbolik in der visuellen Kultur der Sowjetunion, [w:] Die Spur des Sputnik. Kulturhistorische Expeditionen ins kosmische Zeitalter, red. I. Polianski i M. Schwarz, Frankfurt, New York 2009, s. 181-209.

[10] Por. M. Schwartz, Die Erfindung des Kosmos..., s. 13-99.

[11] Por. I. Adamović, Sputnik Pop. Děti - rakety roboti, [w:] Planeta Eden. Svět zítřka v socialistickém 
na ulicach bilety na Księżyc[12]. Za sprawą tych fenomenów miliony obywateli i obywatelek ludowych republik uwierzyły, że już wkrótce kosmos będzie w zasięgu ręki dla niemal każdego.

W kontekście Milczacej gwiazdy dostrzegalny jest bardzo złożony zestaw zamiarów i motywacji związanych z przemianami, jakie dokonywały się w NRD w trakcie pierwszej fazy wyścigu kosmicznego. Z jednej strony ujawnia się w jej przypadku logiczne podążanie za narzucanymi przez Związek Radziecki trendami - duża, międzynarodowa, tworzona z produkcyjnym rozmachem superprodukcja fantastycznonaukowa miała stać się kolejnym użytecznym odwilżowym narzędziem, które nasycało umysły widzów odpowiednią ideologią, mając jednocześnie oddziaływać na ich żądną rozrywki wyobraźnię za pomocą imponujących sekwencji startu rakiety oraz scen eksploracji szczątków nieznanej cywilizacji[13]. Z drugiej strony istotna wydaje się synergia, za sprawą której Milczaca gwiazda jeszcze lepiej mogła propagować wiarę w komunizm (teraz jako projekt już wręcz galaktyczny) oraz poprawić frekwencję w enerdowskich kinach. Synergia ta polegała na tym, że eksplozja popularności tematyki kosmicznej z wzajemnością zasilała inny fenomen, jaki był powiązany za tym filmowym przedsięwzięciem.

Celem całej produkcji miało być bowiem również zdyskontowanie wcześniejszych sukcesów literatury fantastycznonaukowej, która w NRD - z przetłumaczonymi na niemiecki już w 1954 roku Astronautami Lema na czele - cieszyła się w latach pięćdziesiątych bardzo dużą poczytnością. Dostrzegłszy popyt na fantastyczne historie, rządząca krajem Socjalistyczna Partia Jedności Niemiec (SED) realizowała nawet własną dyskursywną i cenzorską strategię odnośnie tej literatury, starając się ją w okresie 1949-1961 dopasować do wzorców socrealizmu oraz nazywając ją własnym, oficjalnym terminem gatunkowym - utopische Literatur (pol. literatura utopijna) [14]. Także serię późniejszych filmów o tematyce kosmicznej i „przyszłościowej” określano na tej samej zasadzie mianem utopische Filme lub, rzadziej, Zukunftsfilme (pol. filmy utopijne i filmy o przyszłości). Określenie „science fiction” było w NRD do lat osiemdziesiątych zakazane ze względu na jego zachodnią, burżuazyjną proweniencję oraz niezgodne z obowiązującą doktryną

Československu 1948-1978, red. I. Adamović, T. Pospiszyl, Praha 2010, s. 62-77.

[12] Zorganizowaną w latach sześćdziesiątych przez amerykańskie linie lotnicze PanAm w Pradze akcję rozdawania biletów na Księżyc udokumentowali Till Steinmetz i Veronika Janatková w produkcji telewizyjnej Bilet na Księżyc (Lístek na Mesíc, 2019). Por. $<$ https://www.imdb.com/title/tt10925514/?ref_=nm_ flmg_edt_1>, dostęp: 26.03.2020.

[13] Po starcie Sputnika szeroka społeczna recepcja kosmicznego sukcesu ZSRR była możliwa "na żywo" tylko za sprawą radiowych sygnałów akustycznych nadawanych przez pierwszego sztucznego satelitę. Matthias Schwartz trafnie zauważa, że pierwsze wschodnioeuropejskie filmy fantastycznonaukowe w tym Milczaca gwiazda - zagwarantowały nowe doświadczenie, dostarczając fikcyjną wprawdzie, ale wciąż spektakularną „widzialność programu kosmicznego". Technologia telewizyjna nie była na przełomie lat pięćdziesiątych i sześćdziesiątych w bloku wschodnim na tyle rozwinięta, żeby umożliwić transmisję na żywo z kosmosu. Poza tym, w przeciwieństwie do Stanów Zjednoczonych, Związek Radziecki starał się utrzymywać przebieg lotów kosmicznych oraz szczegóły technicznej budowy statków w ścisłej tajemnicy. Por. M. Schwartz, Die Erfindung des Kosmos..., s. 135. [14] Por. S. Fritzsche, Science Fiction Literature in East Germany, Oxford, New York 2006, s. 67-102. 
treści. Utopijne dzieła literackie i filmowe nie miały, tak jak utwory amerykańskie czy brytyjskie, epatować przemocą, nieufnością wobec technologii, paranoicznym strachem przed obcością ani niewiarygodnym i niezgodnym $\mathrm{z}$ wykładnią materializmu futuryzmem. W zamian powinny one - jak zwięźle i w duchu socrealizmu stwierdziła niegdysiejsza dramaturg zespołu filmowego Roter Kreis, Thea Richter - być ściśle „związane z teraźniejszością, pokazując to, co możliwe w sferze naukowo-technicznej, oraz to, co konieczne w sferze społecznej”[15].

Pierwsze lata wyścigu kosmicznego - choć w dyskursach wschodnioeuropejskiej propagandy były czasem nowego otwarcia, optymizmu i triumfalnego wyjścia $\mathrm{z}$ fazy powojennej odbudowy - były równolegle okresem spotęgowania napięć w ramach zimnej wojny. Pomimo zapewnień Chruszczowa o woli pokojowej koegzystencji konfliktowe nastawienie na obszarze realnej polityki militarnej systematycznie rosło. Między 1955 a 1960 rokiem całkowita liczba aktywnych głowic atomowych na świecie wzrosła z 2636 do 20285 sztuk[16]. Po starcie Sputnika oba skonfliktowane mocarstwa zaczęły się obawiać, że przeciwnik będzie wkrótce w stanie atakować z orbity Ziemi. W 1961 roku w Berlinie stanął mur, co doprowadziło do znaczącego ochłodzenia wzajemnych stosunków oraz ostatecznie pogrzebało plany zamierzanego jeszcze przed kilku laty zjednoczenia Niemiec. Po kryzysie kubańskim, który nastąpił w 1962 roku i był jedną z najgroźniejszych eskalacji na osi Stany Zjednoczone - ZSRR, skumulowany arsenał znajdujący się w posiadaniu obu stron konfliktu zwiększył się o kolejne 9000 głowic[17].

Milcząca gwiazda wyraźnie odzwierciedla również ten wątek kultury i polityki tamtych czasów, będąc spektakularnym filmem o pionierskiej misji kosmicznej, w który wpleciono jednoznaczne antyatomowe przesłanie. Co istotne, konstrukcja tego wątku w filmie znacznie odbiega od charakterystyki jego pierwowzoru w również dysponującej pacyfistycznym przesłaniem książce Lema. W Astronautach skojarzeń z realnymi miejscami, podziałami politycznymi czy konkretnymi doświadczeniami wojennymi znajdziemy niewiele, podczas gdy w Milczacej gwieździe wszystko podporządkowane jest oficjalnej narracji Związku Radzieckiego na temat antynuklearnego pacyfizmu, a potencjalni winni ewentualnej regresji międzynarodowego i międzyplanetarnego zaufania nazwani są niemalże wprost.

Zgodnie z zakłamaną polityką zagraniczną ZSRR cały blok wschodni był wówczas prezentowany jako progresywny filar międzynarodowego pokoju oraz zmuszoną do obrony ofiarę paranoidalnego, kapitalistycznego militaryzmu amerykańskiego. W filmie Maetziga światowe stosunki spolaryzowane są w analogiczny sposób. Postacią

[15] Signale - Ein Weltraumabenteuer, „Film für Sie" 1970, nr 66. Cyt za. R. Schenk, Ładna zabawka, czyli historia powstania niemiecko-polskiego filmu „Sygnaty MMXX" Gottfrieda Kolditza, [w:] W drodze do sasiada: polsko-niemieckie spotkania filmowe, red.

\section{Pacyfizm} i internacjonalizm 
wprost przestrzegającą przed wyścigiem zbrojeń oraz niewłaściwym wykorzystaniem energii atomowej stała się nieobecna w powieści Lema, ale kluczowa w narracji filmu lekarka Ogimura, która, pomimo upływu lat, wciąż żyje traumą Hiroszimy. Porównania wenusjańskiej autodestrukcji do dokonanego przez Stany Zjednoczone atomowego ataku na Japonię wprowadzane są w filmie kilkakrotnie. Poza tym do scenariusza dopisano na pewnym etapie produkcji niepojawiającą się u Lema scenę spotkania amerykańskich decydentów w Nowym Jorku. W tej osobliwej sekwencji gremium sfrustrowanych, nerwowo popijających whisky i palących cygara naukowców zza oceanu (ucieleśniających niemieckich inżynierów rakietowych pracujących po wojnie dla USA [18]) dywaguje, czy, zamiast lecieć na Wenus, nie lepiej byłoby prewencyjnie zaatakować sąsiednią planetę - w domyśle oczywiście za pomocą bomb.

Warto zaznaczyć, że pacyfizm jest w Milczącej gwieździe ściśle sparowany z komunistyczną koncepcją internacjonalizmu. Żadna inna wschodnioeuropejska produkcja fantastycznonaukowa $\mathrm{z}$ tego okresu nie kładzie tak dużego nacisku na doskonałą współpracę międzynarodowego składu pokojowej misji rozpoznawczej na obcej planecie. W ramach prostych i szczerych interakcji z otaczającym (wszech)światem protagoniści filmu są prezentowani jako ludzkie monumenty idei międzynarodowej integracji oraz jako jednostki dysponujące w pełni wykształconą „osobowością socjalistyczną” [19]. Najważniejsze dla tych wszechstronnych naukowców i techników są: racjonalizm, pracowitość, absolutne poświęcenie dla spraw ogółu i losów przyszłych pokoleń oraz sceptycyzm wobec zgubnych podszeptów indywidualizmu.

Co ciekawe, propagowanie komunistycznego internacjonalizmu nie idzie w filmie Maetziga w parze z pożądaną przez marksizm-leninizm redukcją myślenia w kategoriach przynależności narodowej i rasowej. Zamiast tego łatwo można dostrzec, że pochodzenie i kolor skóry poszczególnych członków kosmicznego kolektywu są nie tylko podkreślane, ale i mocno sfunkcjonalizowane. Na czele kolektywu zdaje się oczywiście stać biały radziecki kapitan Arseniew - nieformalny patriarcha zespołu. Pochodzący ze Stanów Zjednoczonych fizyk Hawling jest prezentowany jako przyjaciel Arseniewa, co wyraźnie odpowiada stereotypowi nawróconego na komunizm, „przekabaconego” na właściwą stronę Amerykanina. Funkcyjnymi przybocznymi radzieckiego kapitana są niemiecki pilot Brinkmann i polski inżynier Sołtyk, co w ciekawy sposób oddaje niepisaną hierarchię państw socjalistycznych oraz odzwierciedla rzeczywisty charakter omawianej koprodukcji (współpraca PRL i NRD przy duchowym wsparciu i zwierzchnictwie ZSRR). Warto przy tym zaznaczyć, że poczciwy lotnik Brinkmann pochodzi nie z RFN lub NRD, ale po prostu z Niemiec, co sugeruje,

[18] Por. S. Fritzsche, Dreams of 'Cosmic Culture' in Der Schweigende Stern [The Silent Star, 1960], [w:] Re-imagining DEFA. East German cinema in its national and transnational contexts, red. S. Allan, S. Heiduschke, New York, Oxford 2016, s. 212-223. Zob. również M. Ivanova, Cinema of collaboration: DEFA coproductions and international exchange in Cold War Europe, Berghahn Books, New York 2020, s. 139-141. [19] S. Fritzsche, Dreams of 'Cosmic Culture' in Der Schweigende Stern [The Silent Star, 1960]..., s. 212. 
że w trakcie powstawania filmu na agendzie wschodnioniemieckiego reżimu wciąż znajdowała się idea zjednoczenia niemieckiego państwa.

Sposoby prezentacji pozostałych, niebiałych protagonistów kosmicznego kolektywu również zdradzają pragmatyczne, łatwe do prześledzenia motywacje ideologiczne, które w dodatku, jak w zniuansowany sposób dowodzi Evan Torner[20], nie są wolne od problematycznych, wręcz rasistowskich z dzisiejszego punktu widzenia uproszczeń. Radiotechnik Talua, pierwszy w historii filmowego gatunku science fiction czarnoskóry kosmonauta, jest jedynym protagonistą bez jednoznacznie określonej przynależności państwowej - pochodzi po prostu z Afryki. Bohater ten, grany przez studiującego wówczas w Lipsku Kenijczyka Juliusa Ongewe, to typowy token black character - rzekomo istotna, ale traktowana w narracji jawnie jako drugorzędna postać o ciemnym kolorze skóry, którą wprowadzono do filmu dla efektu ideologicznego odwołującego się do ideału równości wszystkich ras i kultur w socjalizmie. Warto przy tym pamiętać, że powstanie Milczącej gwiazdy zbiegło się w czasie z rozgrywającą się między komunistycznym Wschodem i kapitalistycznym Zachodem wojną ideologiczną na temat dekolonizacji kontynentu afrykańskiego.

Dalej, wspomniana japońska lekarka Ogimura, chiński biolog i językoznawca Czen Yu oraz hinduski matematyk Sikarna (grany przez wschodnioniemieckiego aktora z brownface) - oprócz tego, że zgodnie ze stereotypami wywodzą się ze starych i szlachetnych kultur azjatyckich - są reprezentantami państw, które albo są komunistyczne, albo przynajmniej sympatyzowały wówczas z blokiem wschodnim lub ucierpiały w wyniku kolonializmu, faszyzmu lub amerykańskiej agresji. Ogimura - jedyna kobieta na pokładzie Kosmokratora, prezentowana naprzemiennie jako ofiara Hiroszimy, obiekt miłosnego zainteresowania Brinkmanna, matkująca mężczyznom opiekunka medyczna oraz hysterical screaming female - w najbardziej wyrazisty sposób łączy w sobie liczne ideologiczne zabiegi obecne w filmie, urastając do roli najbardziej frapującej badawczo postaci[21].

Pierwsza koncepcja projektu Milczacej gwiazdy powstała w PRL w połowie lat pięćdziesiątych. Autorstwo pomysłu na ekranizację prozy Stanisława Lema można $\mathrm{z}$ dużą dozą pewności przypisać Krzysztofowi Teodorowi Toeplitzowi, który w latach 1955-1957 był kierownikiem literackim nowo powstałego Zespołu Filmowego „Kadr”. Lem miał wówczas za sobą dwa pierwsze sukcesy jako autor tekstów fantastycznonaukowych. W 1951 roku opublikował debiutancką powieść

\section{Kosmiczna}

superprodukcja
[20] E. Torner, Casting for socialist Earth: Multicultural whiteness in the East German/Polish science fiction film Silent Star, [w:] The Liverpool Companion to World Science Fiction, red. S. Fritzsche, Liverpool 2015, s. $130-149$.
[21] Por. ibidem; E. Näripea, Work in outer space: Notes on Eastern European science fiction cinema, [w:] Work in Cinema, red. E. Mazierska, New York 2013, s. 216-218; G. Wiechmann, Leit- und Feindbilder im Science-fiction-Film. Die DDR-Produktion DER SCHWEIGENDE STERN, [w:] Leit- und Feindbilder in DDR-Medien, Bonn 1997, s. 22. 
Astronauci, a w latach 1953-1954 ukazywały się w „Przekroju” kolejne odcinki powieści Obłok Magellana. Oba teksty zalicza się dziś do krótkiego socrealistycznego etapu twórczości pisarza. Lem w kolejnych dekadach wyraźnie się względem tej fazy dystansował, twierdząc, że w obu powieściach - pisanych głównie dla łatwego zarobku - na poziomie ideologicznym chodziło nie o propagowanie ideałów marksizmu, lecz o wyrażenie jego ówczesnej fascynacji technologiczną utopią. Astronauci stali się czytelniczym hitem nie tylko w PRL, ale także w innych krajach socjalistycznych. Po tłumaczeniu enerdowskim z 1954 roku szybko ukazały się również tłumaczenie czeskie (1956) i rosyjskie (1957).

Toeplitz pod koniec 1955 roku korespondencyjnie przedstawił Lemowi pomysł stworzenia filmu będącego hybrydą wątków pochodzących z Astronautów i Obłoku Magellana. Jak ustalił biograf pisarza Wojciech Orliński, pierwszym kandydatem na reżysera miał być ponoć sam Jerzy Kawalerowicz [22]. Lem wyraził sceptycyzm co do karkołomnego pomysłu połączenia obu powieści, powołując się na oczekiwania szerokiej publiczności oraz argument niewystarczającej atrakcyjności takiego filmu. W zamian zaproponował skupienie się w scenariuszu na jednym, możliwie najbardziej atrakcyjnym wątku z Astronautów[23].

Nie znając dokładnej treści korespondencji Toeplitza z Lemem, trudno ustalić, czy idea fantastycznonaukowej ekranizacji rzeczywiście narodziła się w głowie pierwszego kierownika literackiego „Kadru”, czy też był on tylko oficjalnym, przekazującym tę koncepcję pośrednikiem działającym z ramienia kierowanej przez niego instytucji. Na podstawie ustaleń Orlińskiego można jednak dostrzec, że w pierwszej fazie tej inicjatywy istotną - być może najistotniejszą - rolę po obu stronach odgrywały wybitnie pragmatyczne kalkulacje. Toeplitz najprawdopodobniej liczył na frekwencyjny i medialny sukces projektu opartego na dwóch popularnych tekstach literackich - projektu, który można by przekuć w produkcyjne osiągnięcie „Kadru”, a także medialnie zainscenizować jako nowe otwarcie na obszarze kina gatunkowego oraz nieoczekiwane wzbogacenie kariery uznanego już wówczas reżysera, jakim po Celulozie (1953) i Pod gwiazda frygijska (1954) był Kawalerowicz. Lemowi, który jako debiutujący pisarz w pierwszej połowie lat pięćdziesiątych nie znajdował się jeszcze w zadowalającej kondycji finansowej, zależało z kolei na zdyskontowaniu sukcesu Astronautów, lukratywnym kontrakcie współscenarzysty oraz podwyższeniu pisarskiej renomy i rozpoznawalności za sprawą faktu szybkiego powstania filmowej adaptacji jednego z jego popularnych tekstów[24].

Korespondencja między Lemem a Toeplitzem trwała kilka miesięcy, podczas których powstała zadowalająca pisarza koncepcja filmu. W pierwszej połowie 1956 roku plany obu autorów zostały jednak częściowo przekreślone, ponieważ decyzją Tadeusza Karpowskiego, ówczesnego dyrektora Komisji Oceny Scenariuszy, projekt przekazano

[22] W. Orliński, Lem: życie nie z tej ziemi, Wołowiec 2017, s. 82.
[23] Ibidem.

[24] Ibidem, s. 110-111. 
Zespołowi Filmowemu „Iluzjon” z rekomendacją jego realizacji we współpracy ze wschodnioniemiecką DEFĄ[25]. O losach wróżącego sukces projektu Toeplitza zadecydowały więc w obrębie państwowych gremiów doraźne motywacje polityczne i propagandowe wynikające z ówczesnej woli pogłębiania współpracy międzynarodowej z państwami sąsiadującymi - głównie z Czechosłowacją i właśnie NRD[26]. Ponadto, słuszny argument za kooperacją z DEFĄ stanowiło przekonanie, że wschodnioniemiecka wytwórnia dysponuje niedostępnym w Polsce, a przecież koniecznym w przypadku tworzenia fantastyki naukowej zapleczem kadrowym i technicznym (efekty specjalne, zdjęcia trickowe, dobrze obsadzone personalnie i wyposażone sprzętowo studia itd.).

Ludwik Starski, jako ówczesny kierownik Iluzjonu, sprawę opracowania wstępnego scenariusza wspólnie z Lemem zlecił Janowi Fethkemu. Trudno dziś ustalić dokładne przyczyny zatrudnienia Fethkego w tym projekcie. Można jednak przypuszczać, iż kluczowe znaczenie miały w przypadku tej personalnej decyzji trzy czynniki. Po pierwsze, Fethke, jako urodzony w Opolu i wychowany w polsko-niemieckiej rodzinie Ślązak, który przed wojną mieszkał w Gdańsku i Berlinie, znał bardzo dobrze język niemiecki. Po drugie, świetnie nadawał się na pośrednika i negocjatora między Iluzjonem a DEFĄ, ponieważ dysponował odpowiednim doświadczeniem scenariopisarskim i reżyserskim - przed wojną, podczas berlińskiej emigracji, współpracował jako scenarzysta z Ufą, a po 1933 roku wyreżyserował w Polsce kilka filmów[27]. Po trzecie wreszcie, wszechstronnie uzdolnionego językowo i artystycznie filmowca cechował entuzjazm dla ponadnarodowych przedsięwzięć i uniwersalnych idei, co wyrażało się między innymi w jego emigracyjnym życiorysie oraz fascynacji językiem esperanto[28]. Warto przy tej okazji wspomnieć, że w czasie przedwojennej współpracy z Ufą Fethke miał okazję poznać Fritza Langa, który po latach wykorzystał napisaną w esperanto powieść fantastyczno-przygodową Fethkego 1000 oczu pana Totka (eo. Mr. Tot aĉetas mil okulojn) jako podstawę scenariusza filmu 1000 oczu doktora Mabuse (Die 1000 Augen des Dr. Mabuse, 1960).

Wiosną 1956 roku Lem z Fethkem oficjalnie rozpoczęli pracę nad nowym scenariuszem. W jej trakcie związani z projektem twórcy - z Lemem włącznie - zostali zaproszeni na wyjazd zapoznawczy do Berlina Wschodniego, gdzie przyjęto ich z nieoczekiwaną atencją [29]. Pierwsza wersja scenariusza trafiła do działu dramaturgicznego wschodnioniemieckiej wytwórni w połowie października 1956 roku.

[25] Ibidem, s. 82.

[26] O kontekście zmiany podejścia do kina niemieckiego, konieczności zacieśniania przyjaźni z NRD oraz o dobrym odbiorze polskiego kina w Niemczech Wschodnich pisze Piotr Zwierzchowski, zob. P. Zwierzchowski, Pęknięty monolit: konteksty polskiego kina socrealistycznego, Bydgoszcz 2005, s. 153-162.
[27] Zob. L. Jockheck, „Jesteśmy internacjonalistami”. Enerdowsko-polska koprodukcja filmu Milczaca gwiazda, [w:] Polska i Niemcy: filmowe granice i sasiedztwa, red. K. Klejsa, Wrocław 2012, s. 113-114. [28] Zob. Jean Forge, <http://www.esperanto.net/ literaturo/roman/fethke.html>, dostęp: 1.06.2020. [29] Zob. W. Orliński, op.cit., s. 82-84. 
Po wpuszczeniu treatmentu Lema i Fethkego w biurokratyczne tryby DEFY rozpoczął się powolny proces przejmowania dominacji nad projektem przez stronę niemiecką. Przedstawiciele enerdowskiej kinematografii - wówczas, jak pisałem wcześniej, powoli otwierającej się na formaty popularne i rozrywkowe - dostrzegli potencjał tej ekranizacji oraz próbowali sprofilować prace nad scenariuszem i produkcją tak, aby przyszłe dzieło realizowało zarówno generalne wytyczne enerdowskiej polityki kulturalnej, jak i kilka doraźnych, strategicznych celów wytwórni.

W kontekście ówczesnych interesów DEFY projekt Milczącej gwiazdy wydawał się dobrą inwestycją, ponieważ bazował na popularnym gatunku literackim, zapowiadał sukces frekwencyjny oraz mógł stać się mocną propozycją eksportową. Dalej, film można by było propagandowo zainscenizować jako postępową produkcję mającą promieniować „nieziemskim” rozmachem oraz wyobrażeniem o wspólnym socjalistycznym przedsięwzięciu filmowym na miarę nowych powojennych czasów - czasów, w których wreszcie można optymistyczne spojrzeć w przyszłość i w których zaczynają zwyciężać idee pokojowej koegzystencji oraz łączącego ludzkość internacjonalizmu. Poza tym, tak imponujący projekt mógł doskonale wyeksponować kapitał twórczy tkwiący w zasobach wytwórni DEFA, realizując przy okazji strategiczne cele sugerowania prestiżu wschodnioniemieckiej wytwórni oraz podwyższania międzynarodowego statusu NRD. W zakresie możliwości kreacyjnych istniejąca od 1946 roku DEFA rzeczywiście miała się czym pochwalić, bowiem zarządzany przez nią przemysł był - na tle odpowiedników w innych państwach bloku wschodniego - wysoce sprofesjonalizowany oraz dysponował bardzo dobrym zapleczem technicznym i rozwiniętą kulturą pracy. Niemcy Wschodnie odziedziczyły zarówno wielu specjalistów, jak i rozbudowaną infrastrukturę po wytwórni Universum-Film-Aktiengesellschaft (UFA), ulokowanej w zajętym pod koniec wojny przez Armię Czerwoną Babelsbergu pod Poczdamem[30]. W latach dwudziestych UFA wydała na świat największe hity kina Republiki Weimarskiej (w tym słynne filmy science fiction Fritza Langa - Metropolis [1927] oraz Kobietę na Księżycu [1929]), a w okresie 1933-1945 była bazą funkcjonującego do samego końca wojny przemysłu filmowego Trzeciej Rzeszy[31].

Milczaca gwiazda miała zachwycić widzów przede wszystkim nowymi technikami obrazowania, jednocześnie podkreślając niedawne osiągnięcia wschodnioniemieckiego przemysłu filmowego na tym obszarze. Film stanowi jedno z pierwszych dzieł dostępnych w szerokoekranowym formacie Totalvision, który był enerdowską kopią

[30] Por. S. Allan, DEFA: An historical overview, [w:] DEFA: East German cinema, 1946-1992, red. S. Allan, J. Sandford, New York 1999, s. 2-5; J. Feinstein, The Triumph of the Ordinary: Depictions of Daily Life in the East German Cinema, 1949-1989, Chapel Hill 2002, s. 28.
[31] Por. D. Berghahn, Hollywood behind the Wall: The Cinema of East Germany, Manchester, New York 2005, s. 11-12; A. Gwóźdź, Zaklinanie rzeczywistości: filmy niemieckie i ich historie 1933-1949, Wrocław 2018, s. 35-205. 
amerykańskiej technologii CinemaScope. Szefostwo DEFY w 1957 roku zleciło opracowanie tej technologii z dość prozaicznego powodu - opłaty licencyjne za CinemaScope przekraczały możliwości finansowe wytwórni. Poza tym, film Maetziga powstał na kolorowej taśmie, co w NRD w latach pięćdziesiątych należało jeszcze do rzadkości. Użyta taśma pochodziła z szybko reaktywowanej po wojnie fabryki materiałów fotochemicznych Agfa ulokowanej w saksońskim kombinacie Bitterfeld-Wolfen. Ów enerdowski produkt, od 1964 roku przemianowany na ORWO (skrót od „Original Wolfen”), był później bardzo popularny w krajach bloku wschodniego i w państwach azjatyckich.

Trzeba wspomnieć również o tym, że Milcząca gwiazda było bardzo zaawansowaną produkcją także w sferze audialnej - zarówno w zakresie użytej techniki, jak w wymiarze akustycznego nasycenia soundtracku. Amerykański badacz Trace Reddell trafnie zauważył, że ze względu na akustyczne wyrafinowanie film Meatziga - wbrew przymiotnikowi użytemu w jego tytule - wydaje się bardzo daleki od milczenia[32]. Film dysponował innowacyjną, czterokanałową ścieżką dźwiękową, która była zarejestrowana i miksowana na nowoczesnej wówczas taśmie magnetycznej (niem. 4-Kanal-Magnetton). Do dziś mogą budzić podziw zastosowane w filmie elektroniczne efekty dźwiękowe oraz ambitna, modernistyczna muzyka skomponowana przez Andrzeja Markowskiego - uznanego polskiego kompozytora, który stworzył tła muzyczne między innymi do Pokolenia (1955, A. Wajda), Popiołów (1965, A. Wajda) czy Pana Wołodyjowskiego (1969, J. Hoffmann).

Rozmach produkcyjny, technologiczne ambicje oraz wola promowania Milczącej gwiazdy za granicą jako prestiżowego dzieła eksportowego przełożyły się jednak na duże ryzyko finansowe oraz liczne przeszkody natury organizacyjnej. Ze względu na fakt, że ani ówczesna telewizja, ani większość kin w bloku wschodnim nie dysponowały urządzeniami obsługującymi format Totalvision, zdjęcia przeciągały się, ponieważ ujęcia trzeba było realizować na ekran standardowy i panoramiczny. Kolejnymi powodami wydłużenia okresu zdjęciowego były problemy komunikacyjne. Zatrudnieni przy filmie członkowie wielonarodowej ekipy - w tym liczni aktorzy zagraniczni (jak na przykład chiński aktor Tang Hua-ta grający Czena Yu) - musieli rozmawiać z pionem reżyserskim za pośrednictwem tłumaczy. Poza tym, po wykonaniu zdjęć trzeba było wykonać polską i niemiecką wersję dubbingową. Ciekawą relację z niełatwego procesu powstawania Milczącej gwiazdy stanowi seria publikowanych w latach 1957-1960 artykułów w czasopismach „Film” i „Ekran”[33].

[32] Zob. T. Reddell, The Sound of Things To Come: An Audible History of the Science Fiction Film, Minneapolis 2018, s. 210.

[33] Zob. między innymi Polsko-niemieccy „Astronauci”, „Film” 1957, nr 33, s. 2; K. Lebiedź, Polska i NRD na szlaku międzyplanetarnym, „Ekran” 1957, nr 25, s. 3;
Z. Ornatowski, Filmowcy NRD w Ekranie, „Ekran” 1959, $\mathrm{nr} 43$ (133), s. 3; E. Dziębowska, Milcząca gwiazda. Korespondencja własna, „Ekran” 1959, nr 20 (110), s. 8-9; J. Peltz, Kosmokrator startuje w Zakopanem, „Film” nr 26 (551), s. 10-11; idem, Kosmokrator wystartowat, „Film” 1960, nr 10 (587), s. 12-13. 
Nakład pracy i środków, jaki ostatecznie zainwestowano w omawiane dzieło, był tak wysoki, że plan finansowy całego projektu opiewał na kwotę ponad 5,5 miliona marek. Większość kosztów poniosła DEFA, ponieważ udział Iluzjonu w budżecie wyniósł tylko 20\%[34]. Uczyniło to Milcząca gwiazdę jednym z wówczas najdroższych filmów enerdowskiej wytwórni - za tę samą wartość dałoby się w latach pięćdziesiątych zrealizować w Niemczech Wschodnich trzy pełnometrażowe produkcje fabularne. Warto również w tym kontekście przywołać anegdotę, wedle której inscenizacja i budowa scenografii do scen dziejących się na Wenus doprowadziły rzekomo do całkowitego wyczerpania rocznego zapasu kleju przemysłowego w NRD[35]. Liczne problematyczne aspekty produkcji skutecznie zniechęciły naczelników wschodnioniemieckiej kinematografii do kolejnych inwestycji na polu fantastyki naukowej - kolejne utopijne dzieło o podróżach w kosmos, ponownie koprodukowane z Polską, powstało w NRD dopiero 10 lat później[36].

Można wręcz stwierdzić, że rozciągnięta na lata 1957-1959 historia produkcyjna Milczacej gwiazdy ostatecznie okazała się historią porażki scenariuszowego i koprodukcyjnego kompromisu, który, jak pisałem powyżej, miał pogodzić pragmatyczne cele wytwórni oraz ideologiczne oczekiwania funkcjonariuszy partyjnych zajmujących się polityką kulturalną. Znalezienie formuły jednocześnie rozrywkowej i upolitycznionej, która zadowoli liczne twórcze i partyjne gremia działające po obu stronach Odry, było w panujących ówcześnie w PRL i NRD warunkach kulturowych, politycznych i ekonomicznych po prostu niemożliwe.

Z powodu ideologicznych nacisków, jakie w fazie prac nad scenariuszem zwierzchnicy wschodnioniemieckiej kinematografii podejmowali wobec twórców i szefostwa DEFY, swój aktywny udział w projekcie szybko odwołał sam Lem. Niezadowolenie pisarza wynikało z faktu, że jego powieść - utwór prezentujący technologiczną utopię oraz dysponujący uniwersalną humanistyczną wymową - na kolejnych etapach zmian w scenariuszu planowano przeobrazić albo w powierzchowną, komercyjną produkcję rozrywkową, albo, do czego rzeczywiście doszło, w ciężkostrawne estetycznie dzieło propagandowe traktujące wszystko z nieznośną, socrealistyczną dosłownością. Ponadto, osobne źródło konfliktów stanowiły podejmowane przez niemieckich decydentów próby zaproszenia do projektu partnera francuskiego oraz zabiegi redukowania producenckiej sprawczości po polskiej stronie - pomimo wcześniejszych zapewnień o kooperacji na zasadzie parytetu. Doszło nawet do tego, że Fethke i Starski w połowie 1958 roku zagrozili zerwaniem umowy, powołując się na argument, że strona polska jest moralnym i formalnym właścicielem praw autorskich do tekstu Lema oraz przedstawicielem poglądów pisarza.

[34] Zob. M. Ivanova, op.cit., s. 138.

[35] Zob. K. Kruschel, Leim für die Venus. Der Science-Fiction-Film in der DDR, [w:] Das Science Fiction

Jahr 2007, red. W. Jeschke, München 2007, s. 803-888.
[36] Chodzi o film Gottfrieda Kolditza Sygnały $M M X X$ (1970), por. R. Schenk, op.cit., s. 72-94. 
Po ponad dwóch latach negocjacji obie strony zaangażowane w projekt zaakceptowały dopiero dwunastą (!) wersję scenariusza, która została ukończona w listopadzie 1958 roku i była sygnowana przez aż sześciu autorów. Warto wspomnieć, że nie widniał na niej podpis samego Lema, który w czołówce filmu został jednak wymieniony jako autor jego literackiej podstawy. Rozciągnięta w czasie, pasywno-agresywna presja Niemców w kwestii podziału obowiązków na planie częściowo przyniosła efekt, ponieważ od końca 1958 roku polska strona de facto oddała pole działania partnerowi, rezygnując z szerszego udziału w procesie zdjęciowym i postprodukcyjnym. Ostatecznie więc owo pierwsze wspólnie tworzone dzieło - promujące w dodatku ideę internacjonalizmu - pozostało manifestacją braterskiej współpracy dwóch socjalistycznych państw tylko na poziomie zapewnień partyjnych oficjeli podczas krajowych premier filmu - 26 lutego w berlińskim kinie Colosseum oraz prawie dwa tygodnie później, 7 marca 1960 roku, w kinie Śląsk w Warszawie. Dokładny przebieg zrekapitulowanej powyżej historii produkcyjnej Milczacej gwiazdy - włącznie z odwołaniami do źródeł dokumentujących przywoływane przeze mnie fakty i dane - przedstawili Stefan Soldovieri[37], Lars Jockheck[38], Agnieszka Nieracka-Ćwikiel[39] i Mariana Ivanova[40].

Pomimo scharakteryzowanych powyżej trudności superprodukcyjny charakter Milczacej gwiazdy okazał się czynnikiem, który zadecydował o niezłym wyniku frekwencyjnym filmu. Według badaczy i świadków frekwencja na pokazach zarówno w PRL, jak i w NRD spełniła oczekiwania decydentów zajmujących się kinematografią. O zadowalającym wyniku filmu w Polsce pisali Starski[41] i Edward Zajiček[42]. Źródła odnoszące się do recepcji w NRD podają konkretne sumy widzów - najbardziej godna zaufania wydaje się przywołana przez Jockhecka liczba 2682047 osób, które pokazywaną w kraju na 61 kopiach Milczącą gwiazdę obejrzały w ciągu ośmiu miesięcy od dnia premiery[43].

Audiowizualna efektowność dzieła Maetziga zapewne osłodziła widzom konfrontację z jego tendencyjną treścią i siermiężną narracją -

[37] S. Soldovieri, Socialists in Outer Space: East German Film's Venusian Adventure, „Film History” 1998, t. 10, nr 3, s. 382-398.

[38] L. Jockheck, op.cit., s. 111-127.

[39] A. Nieracka-Ćwikiel, „Milcząca gwiazda”, czyli o historii pewnej koprodukcji [w:] Socrealizm: fabuty, komunikaty, ikony, K. Stępnik, M. Piechota (red.), Lublin 2006, s. 245-252.

[40] Zob. M. Ivanova, op.cit., s. 135-151.

[41] Zob. L. Jockheck, op.cit., s. 111.

[42] Por. E. Zajiček, Poza ekranem: kinematografia polska 1896-2005, Warszawa 2009, s. 207.

[43] Zob. L. Jockheck, op.cit., s. 111. Thomas Heimann pisze o 2,1 mln widzów w NRD, zob. T. Heimann, Freundschaft - Przyjaźń? Kamerablicke auf den Nachbarn: filmkulturelle Beziehungen der DDR mit der VR Polen 1945-199o, Berlin 2017, s. 300. Soldovieri przywołuje liczbę ponad 200 ooo widzów w pierwszych 13 tygodniach wyświetlania, zob. S. Soldovieri, op.cit., s. 394. Portal insidekino.de podaje skumulowaną dla okresu 1960-199o liczbę 4375094 widzów, zob. <http://www.insidekino.de/DJahr/DDRAlltimeDeutsch.htm>, dostęp: 29.03.2020. W latach 1949-1990 populacja NRD liczyła około $17 \mathrm{mln}$, por. <https://de.statista.com/statistik/daten/studie/249217/ umfrage/bevoelkerung-der-ddr/>, dostęp: 29.03.2020. 
o takim wrażeniu niechybnie świadczą publikowane po premierze teksty krytyczne na temat filmu[44]. Recenzenci z obu zaangażowanych w produkcję krajów głównie podkreślali osiągnięcia techniczne filmu (scenografia i dekoracje, ścieżka dźwiękowa, scena startu Kosmokratora), jednocześnie krytykując - w Polsce znacznie bardziej otwarcie niż w NRD - toporną inscenizację, dosłowne zabiegi ideologiczne oraz patetyczne zakończenie. Poza tym refren wielu recenzji stanowiło uznanie dla pracy międzynarodowej ekipy filmu. W szczególności zwracano uwagę na postać Ogimury oraz na umiejętności grającej tę bohaterkę, francusko-japońskiej aktorki Yoko Tani.

Na usługach doktryny

W niniejszym tekście podsumowałem kluczowe wątki badawcze dotyczące treści, narracji, trajektorii powstania oraz recepcji Milczacej gwiazdy. Szczegółowe rekonstrukcje oraz dokładniejsze dane można znaleźć w cytowanych przeze mnie źródłach. Poza tym wiele faktów na temat filmu Maetziga wciąż czeka na odkrycie w archiwach - szczególnie tych znajdujących się w Polsce[45]. Tworząc powyższe preludium do szerokiego case study, miałem na celu ukazanie, jak dalece - na każdym etapie powstawania oraz w niemal każdym wymiarze narracji i inscenizacji - produkcja ta była dziełem stłamszonym przez politycznych decydentów, którym zależało na kreowaniu odpowiedniego efektu ideologicznego, jak również na umiejętnym sterowaniu uwagą enerdowskiej publiczności w bardzo specyficznej politycznie sytuacji kulturowej końca lat pięćdziesiątych.

W formie, w jakiej ostatecznie powstała, Milcząca gwiazda zdaje się stanowić przypadek zupełnie osobny i wręcz bezprecedensowy, jeśli chodzi o historię filmowego science fiction - niezwykle rozległego, wielozadaniowego, w istocie niedefiniowalnego megagatunku, który zazwyczaj służył i do dziś służy 1) producentom skupionym na tworzeniu komercyjnej rozrywki, 2) przemysłom filmowym na obszarze implementowania nowych technologii audiowizualnych lub 3) autorom wykorzystującym motywy sf $\mathrm{w}$ ramach indywidualnych, często modernistycznych z ducha poszukiwań artystycznych i intelektualnych. Tę trzecią ścieżkę rozwoju światowe kino oczywiście zawdzięcza

[44] Zob. między innymi H. Hofmann, Utopie mit Realitätsanspruch, „Deutsche Filmkunst” 1960, nr 4, s. 116-118; H. Kähler, Der schweigende Stern, „Junge Welt" 1960, nr 50 (27 lutego 1960), s. 4; H. Knietzsch, Lob der technischen Phantasie, „Neues Deutschland” 1960, nr 59 (28 lutego 1960), s. 4; K. von Schnitzler, Der schweigende Stern, „Filmkunst” 1960, nr 6, s. 5; L. Hitzinger, M. Heidel, Utopie im Kreuzverhör, „Neue Berliner Illustrierte" 1960, nr 3, s. 2-5; A. Helman, Milczaca gwiazda w czasie i przestrzeni, „Ekran” 1960, nr 12 (154), s. 4; S. Morawski, Granice sztuki, „Ekran” 1960, nr 14 (156), s. 4; Z. Kałużyński, Pierwsi Polacy na planecie Wenus!, „Polityka” 196o, nr 12, s. 10;
J. Płażewski, Film w czasie przyszłym, „Przegląd Kulturalny” 1960, nr 12, s. 19; B. Michałek, Astronautyka i plazma, „Nowa Kultura” 1960, nr 12; K.T. Toeplitz, Śmieszny strach, „Świat” 1960, nr 12, s. 14. [45] Mam na myśli wszelką korespondencję oraz dokumentację, jaka odnośnie Milczącej gwiazdy $\mathrm{z}$ pewnością powstawała $\mathrm{w}$ ramach pracy polskich instytucji zaangażowanych $\mathrm{w}$ tę produkcję. Jedyną autorką, która w kontekście filmu szerzej odwoływała się do źródeł archiwalnych Naczelnego Zarządu Kinematografii oraz Ministerstwa Kultury i Sztuki PRL, była Agnieszka Nieracka-Ćwikiel, zob. A. Nieracka-Ćwikiel, op.cit., s. 248 i n. 
przełomowemu dla gatunku filmowi 20o1: Odyseja kosmiczna (1968) Stanleya Kubricka.

Przypadek enerdowskiego gatunku filmu utopijnego - zainicjowanego przez Milczaca gwiazdę i kontynuowanego z miernymi sukcesami przez trzy kolejne dekady[46] - nie podporządkowuje się w pełni żadnej z wymienionych powyżej tendencji, ponieważ stał się przede wszystkim narzędziem wykorzystywanym do realizowania ściśle projektowanej, głęboko zideologizowanej polityki kulturalnej. Prestiż, dostarczanie bezpiecznej ideowo filmowej rozrywki, rentowność produkcji czy sukces frekwencyjny były motywacjami dla procedowania projektu Milczacej gwiazdy - niemniej, jak pokazuje analiza źródeł historycznych, były to cele i czynniki ostatecznie drugorzędne, z których reżyser, decydenci wytwórni i przedstawiciele ministerstwa byli w stanie częściowo zrezygnować, pragnąc zachować odpowiednią wymowę doktrynalną filmu, a także próbując utrzymać przy życiu tę dość trudną ze względów politycznych koprodukcję.

Dogłębna historyczna rekonstrukcja warunków powstawania Milczącej gwiazdy i kilku innych, podobnych do niej wschodnioeuropejskich filmów z okresu wyścigu kosmicznego[47] wydaje się najlepszą metodą, żeby doprowadzić do koniecznego zniuansowania myślenia o realizowanej w byłym bloku wschodnim fantastyce naukowej. Zarówno we współczesnych badaniach filmoznawczych, jak i w zachodniej publicystyce filmowej wciąż zauważalna jest skłonność do zwracania uwagi przede wszystkim na dzieła uznawane dziś za kultowe, spośród których w czołówce niezmiennie znajdują się kanoniczne utwory Andrieja Tarkowskiego, Piotra Szulkina czy Konstantina Łopuszańskiego. Nierzadko filmy tych reżyserów uznaje się za swoistą kulminację gatunku w jego wschodnioeuropejskim wydaniu.

Co więcej, w ramach takiego myślenia często ujawnia się również „zachodniocentryczność" podejmowanych obserwacji. Wyraża się ona, po pierwsze, w postrzeganiu amerykańskich i brytyjskich manifestacji gatunku jako właściwych, niekwestionowanych wzorców jego rozwoju oraz, po drugie, projektowaniu badawczych konkluzji odnośnie zachodnich kultur popularnych na fenomeny gatunkowe, jakie zaistniały między 1945 a 1990 rokiem w Europie Środkowej i Wschodniej. A przecież oczywiste wydaje się, że wykształcające się w latach pięćdziesiątych i sześćdziesiątych kultury popularne w każdej lokalnej odmianie socjalizmu (radzieckiej, polskiej, węgierskiej, wschodnioniemieckiej, rumuńskiej itd.) były bardzo różne - zdeterminowane przez inne wydarzenia historyczne, uwarunkowane przez różne tradycje, zarządza-

[46] Por. M. Peplinski, Wzlot, orbitowanie i upadek. Filmowa fantastyka naukowa w Niemieckiej Republice Demokratycznej [w:] Europejskie kino gatunków 2, red. P. Kletowski, M. Peplinski, Kraków 2020, s. 197-216. [47] Były to radzieckie filmy Droga do gwiazd (1957, P. Kłuszancew), Niebo wzywa (1959, M. Karjukow, A. Kozyr), Byłem satelitą słońca (1959, W. Morgen- stern), Planeta burz (1962, P. Kłuszancew), Naprzeciw marzeniu (ZSRR, 1963, M. Karjukow, O. Koberidze) oraz wspomniana na wstępie, czechosłowacka Ikaria XB 1. Por. M. Schwartz, Archaeologies of a Past Future. Science Fiction Films from Communist Eastern Europe [w:] Future imperfect: science-fiction-film, red. R. Rother, A. Schaefer, Berlin 2017, s. 96-117. 
ne przez mniej lub bardziej pryncypialne reżimy partyjne, sterowane przez inaczej zarządzane i rozwijane media. Zachodni entertainment z kinem hollywoodzkim na czele na pewno był dla tych kultur istotnym odniesieniem - ale wszak nie zawsze pozytywnym, branym na serio oraz możliwym do funkcjonalnego skopiowania na gruncie słabo sobie radzących gospodarek centralistycznych.

W ramach podsumowywania wschodnioeuropejskiej fantastyki naukowej przez pryzmat rozwoju gatunku na Zachodzie wciąż badawczo zaniedbywane pozostają dziesiątki filmów starszych, przeciętnych na poziomie estetyki lub, co w zasadzie stanowi osobny obszar badawczy, łączących sf z innymi konwencjami (na przykład kino sf dla dzieci i młodzieży). Właśnie te produkcje, a nie późne filmy autorskie, stanowiły trzon eklektycznej filmowej sf, w którą swego czasu - nie tylko w dobrze już zbadanych latach siedemdziesiątych i osiemdziesiątych, ale również w pierwszych dwóch dekadach powojennych poszczególne socjalistyczne kinematografie i telewizje inwestowały ogromne środki.

Trzeba wszystkie te filmy - zarówno arcydzieła Tarkowskiego, jak i enerdowskie superprodukcje, pierwsze czechosłowackie komedie sf[48], estońskie animacje fantastycznonaukowe[49] oraz popularny radziecki młodzieżowy dyptyk filmowy o nastolatkach lecących na Kasjopeję[50] - badać w stricte historycznym kluczu, starając się w przypadku każdego efemerycznego fenomenu zrekonstruować sieć głównych motywacji i czynników, jakie warunkowały działania poszczególnych „agentów” - twórców, producentów, szefów wytwórni, decydentów partyjnych, cenzury, działaczy państwowych organizacji związanych z danymi przedsięwzięciami. Skupienie tylko na estetyce oraz mechanicznym interpretowaniu treści filmów w relacji do abstrakcyjnych założeń marksizmu-leninizmu lub stereotypowych tez odnośnie wschodnioeuropejskiego komunizmu jest niewystarczające. Jeszcze gorszym pomysłem wydaje się szukanie nadrzędnej teleologii oraz tworzenie terminu parasolowego dla całego regionu - działania takie mogą ostatecznie tylko oddalić badaczkę od intuicji klasyfikowania licznych, równolegle istniejących sposobów, w jakie gatunek był projektowany i wykorzystywany politycznie w każdym ze wschodnioeuropejskich reżimów.

Tylko dogłębnie zogniskowane na danej kinematografii (oraz, tym samym, nadrzędnej dla niej, narodowej kulturze popularnej) badania historyczne pomogą ustalić wachlarz empirycznie uogólnionych,

[48] Zob. filmy Człowiek z pierwszego stulecia (1961, O. Lipský), Kto chce zabić Jessii? (1966, V. Vorlíček), Panowie, zabiłem Einsteina! (1969, O. Lipský) lub Jest pan wdowa, proszę pana! (1971, V. Vorlíček). Por. J. Trzupek, W krainie Golema i robota - uwagi o czechosłowackim filmie fantastycznym, [w:] Europejskie kino gatunków, red. P. Kletowski, Kraków 2016, s. 209-224.
[49] Zob. E. Näripea, Soviet Estonian animated science fiction: Avo Paistik's mischievous universes, "Studies in Eastern European Cinema” 2017, t. 8, nr 2. [50] Zob. filmy W drodze na Kasjopeję (1973, R. Wiktorow) i Spotkanie na Kasjopei (1974, R. Wiktorow). 
ale wciąż lokalnych norm dla danego zjawiska kultury popularnej. Mówiąc prościej, żeby skutecznie zmapować wschodnioeuropejskie science fiction, należy ostrożnie i z dbałością bezstronnego historyka porównywać utopischer Film z NRD, filmową i telewizyjną fantastykę naukową z PRL, socrealistyczną Научная фантастика (nаисzпаја fantastika) z ZSRR, produkowany w praskim Barrandovie, otwarcie rozrywkowy vědecko-fantastický film itd.

Adamović I., Sputnik Pop. Děti - rakety - roboti, [w:] Planeta Eden. Svět zítřka v socialistickém Československu 1948-1978, red. I. Adamović, T. Pospiszyl, Praha 2010

Allan S., DEFA: An Historical Overview [w:] DEFA: East German Cinema, 19461992, red. S. Allan, J. Sandford, New York 1999

Berghahn D., Hollywood Behind the Wall: The cinema of East Germany, Manchester, New York 2005

Die erfolgreichsten DDR-Filme in der DDR, <http://www.insidekino.de/DJahr/ DDRAlltimeDeutsch.htm>, dostęp: 29.03.2020

Dziębowska E., Milczaca gwiazda. Korespondencja własna, „Ekran” 1959, nr 20 (110)

Feinstein J., The Triumph of the Ordinary: depictions of daily life in the East German cinema, 1949-1989, Chapel Hill 2002

Fritzsche S., Dreams of 'cosmic culture' in Der Schweigende Stern [The Silent Star, 1960], [w:] Re-imagining DEFA. East German cinema in its national and transnational contexts, red. S. Allan, S. Heiduschke, New York, Oxford 2016, s. 212-223

Fritzsche S., Science Fiction Literature in East Germany, Oxford, New York 2006

Gwóźdź A., Kino na biegunach: filmy niemieckie i ich historie 1949-1991, Gdańsk 2018

Gwóźdź A., Zaklinanie rzeczywistości: filmy niemieckie i ich historie 1933-1949, Wrocław 2018

Heidel M., Hitzinger L., Utopie im Kreuzverhör, „Neue Berliner Illustrierte” 1960, nr 3

Heimann T., Freundschaft - Przyjaźń? Kamerablicke auf den Nachbarn: filmkulturelle Beziehungen der DDR mit der VR Polen 1945-1990, Berlin 2017

Helman A., Milczaca gwiazda w czasie i przestrzeni, „Ekran”1960, nr 12 (154)

Hofmann H., Utopie mit Realitätsanspruch, „Deutsche Filmkunst” 1960, nr 4

Ivanova M., Cinema of Collaboration: DEFA coproductions and international exchange in Cold War Europe, New York 2020

Jockheck L., "Jesteśmy internacjonalistami”. Enerdowsko-polska koprodukcja filmu Milczaca gwiazda, [w:] Polska i Niemcy: filmowe granice i sasiedztwa, red. K. Klejsa, Wrocław 2012

Kałużyński Z., Pierwsi Polacy na planecie Wenus!, „Polityka” 1960, nr 12

Kähler H., Der schweigende Stern, „Junge Welt” 1960, nr 50 (27 lutego 1960)

Kozik Z., Niemcy w NRD a polskie kryzysy 1956 i 1980-1981, Piotrków Trybunalski 1998

Knietzsch H., Lob der technischen Phantasie, „Neues Deutschland” 1960, nr 59 (28 lutego 1960)

Kruschel K., Leim für die Venus. Der Science-Fiction-Film in der DDR [w:] Das Science Fiction Jahr 2007, red. W. Jeschke, München 2007

Lebiedź K., Polska i NRD na szlaku międzyplanetarnym, „Ekran” 1957, nr 25

Michałek B., Astronautyka i plazma, „Nowa Kultura” 1960, nr 12 
Morawski S., Granice sztuki, „Ekran” 1960, nr 14 (156)

Näripea E., Soviet Estonian animated science fiction: Avo Paistik's mischievous universes, „Studies in Eastern European Cinema” 2017, t. 8, nr 2

Näripea E., Work in outer space: Notes on Eastern European science fiction cinema [w:] Work in Cinema, red. E. Mazierska, New York 2013

Nieracka-Ćwikiel A., „Milczaca gwiazda”, czyli o historii pewnej koprodukcji, [w:] Socrealizm: fabuly, komunikaty, ikony, red. K. Stępnik, M. Piechota, Lublin 2006

Norris R.S., Kristensen H.M., Global nuclear weapons inventories, 1945-2010, „Bulletin of the Atomic Scientists" 2010, t. 66, nr 4

Orliński W., Lem. Życie nie z tej ziemi, Wołowiec 2017

Ornatowski Z., Filmowcy NRD w Ekranie, „Ekran” 1959, nr 43 (133)

Peltz J., Kosmokrator startuje w Zakopanem, „Film” 1959, nr 26 (551)

Peltz J., Kosmokrator wystartowat, „Film” 1960, nr 10 (587)

Peplinski M., Niebiański statek, „Ekrany” 2018, nr 1 (nr 38)

Peplinski M., Wzlot, orbitowanie i upadek. Filmowa fantastyka naukowa w Niemieckiej Republice Demokratycznej, [w:] Europejskie kino gatunków II, red. P. Kletowski, M. Peplinski, Kraków 2020

Pischel C., Geschichten nach der Geschichte. Die zeitlichen Faltungen und Schichtungen des Science-Fiction-Films im Dienst des Staatssozialismus, [w:] Die Zukunft ist jetzt: Science-Fiction-Kino als audio-visueller Entwurf von Geschichte(n), Räumen und Klängen, red. A. Power, D. González de Reufels, R. Greiner, W. Pauleit, Berlin 2016

Płażewski J., Film w czasie przyszłym, „Przegląd Kulturalny” 1960, nr 12

Polsko-niemieccy „Astronauci”, „Film” 1957, nr 33

Reddell T., The Sound of Things to Come. An Audible History of the Science Fiction Film, Minneapolis 2018

Richers J., Himmelssturm, Raumfahrt und „kosmische” Symbolik in der visuellen Kultur der Sowjetunion, [w:] Die Spur des Sputnik. Kulturhistorische Expeditionen ins kosmische Zeitalter, red. I. Polianski, M. Schwarz, Frankfurt, New York 2009

Schenk R., Ładna zabawka, czyli historia powstania niemiecko-polskiego filmu „Sygnaty MMXX" Gottfrieda Kolditza, [w:] W drodze do sasiada: polsko-niemieckie spotkania filmowe, A. Dębski, A. Gwóźdź (red.), Wrocław 2013

Schnitzler K. von, Der schweigende Stern, „Filmkunst” 1960, 7, nr 6

Schwartz M., Archaeologies of a past future. Science fiction films from communist Eastern Europe, [w:] Future Imperfect: science-fiction-film, red. R. Rother, A. Schaefer, Berlin 2017

Schwartz M., Die Erfindung des Kosmos: zur sowjetischen Science Fiction und populärwissenschaftlichen Publizistik vom Sputnikflug bis zum Ende der Tauwetterzeit, Frankfurt am Main, New York 2003

Schwartz M., The Heavens Call, <http://sensesofcinema.com/2007/cteq/heavens-call/>, dostęp: 26.03.2020

Signale - Ein Weltraumabenteuer, „Film für Sie” 1970, nr 66

Soldovieri S., Socialists in Outer Space: East German film's Venusian Adventure, „Film History” 1998, t. 10, nr 3

Śliwińska K., Socrealizm w PRL i NRD, Poznań 2006

Toeplitz K.T., Śmieszny strach, „Świat” 1960, nr 12

Torner E., Casting for socialist Earth: Multicultural whiteness in the East German/ Polish science fiction film Silent Star, [w:] The Liverpool Companion to World Science Fiction, red. S. Fritzsche, Liverpool 2015, s. 130-149

Trzupek J., W krainie Golema i robota - uwagi o czechostowackim filmie fantastycznym, [w:] Europejskie kino gatunków, red. P. Kletowski, Kraków 2016 
Uhliřova M., Voyage through Space, Time and Utopian Modernism in Ikarie XB 1, [w:] L. Česálková, Czech Cinema Revisited: politics, aesthetics, genres and techniques, Prague 2017

Wiechmann G., Leit- und Feindbilder im Science-fiction-Film. Die DDR-Produktion DER SCHWEIGENDE STERN, [w:] Leit- und Feindbilder in DDR-Medien, Bundeszentrale für politische Bildung, Schriftenreihe Medienberatung, Bonn 1997 Zajiček E., Poza ekranem: kinematografia polska 1896-2005, Warszawa 2009

Zwierzchowski P., Pęknięty monolit: konteksty polskiego kina socrealistycznego, Bydgoszcz 2005

<http://www.kinokompendium.de/kosmos_kino_berlin.htm>, dostęp: 26.03.2020

<https://www.gdanskstrefa.com/kino-kosmos-gdansk-kalisz-zambrow/>, dostęp: 26.03.2020

<https://fotopolska.eu/>, dostęp: 26.03.2020 